\title{
Occupation Skill Cultivating Strategies for the Talents Majoring in Business English against the Background of China FTA
}

\author{
Xue Dong \\ Xi'an Fanyi University, Xi'an City, Shaanxi Province, 710105, China
}

Keywords: China FTA; Business English; Occupation skill; Cultivation strategy

\begin{abstract}
China FTA(China Free Trade Zone) construction will bring a large number of foreign investors and foreign enterprises, and Business English is the essential condition of communication and negotiation. Therefore, the talents majoring in Business English will be the most needed talents. As an international language, English plays a crucial role in international business activities. Therefore, the occupation skill cultivation of talents majoring in Business English should be paid enough attention to. Based on the author's teaching practice, this paper firstly analyzed the Business English Majors' occupation ability, and then analyzed the problems existing in occupation ability cultivation for students majoring in Business English, finally put forward the countermeasures for cultivating.
\end{abstract}

\section{Introduction}

China FTA refers to the multifunctional economic special zone established inside or outside the country implementing preferential taxation and special customs supervision policies as main means with the purpose of liberalization and facilitation of trade. The development of economy in Chinese FTA needs a large number of talents majoring in Business English. Therefore, cultivation Business English talents with strong business ability is very urgent. The importance of occupation ability cultivation has been agreed by the researchers at all walks of life, and will be regarded as an important link to cultivate sustainable development ability of students. Today, occupation-oriented talents are the real needs of the society. For Business English majors, they need a high level of language and a strong comprehensive quality, so that to be able to quickly adapt to the vacancy when work or environment change. Only graduates with professional competence and professional core competence developing in a balanced way, will they be able to successfully obtain employment.

\section{Professional Ability Analysis on Business English Majors}

Occupation education ability is the direction of the world's occupation education reform. It takes a comprehensive analysis of professional role activities as a starting point, and it regards providing the abilities that industry or society fulfill the responsibilities required by the trainees as its principles. It emphasizes the dominant position of students in the learning process; its core is how to make the students have engaged in the actual capability required by an occupation. In other words, standard education is a type of education to cultivate technical talents with comprehensive professional ability and comprehensive quality for the production, construction, management and service. Higher vocational education shoulders the important task of cultivating high quality and skilled talents for social and economic development. The "skill type" refers to the students' occupation ability. In modern society, the professional ability of students determines the level of their career development and the possibility of development. Business English majors mainly engaged in the works, including foreign enterprise management, documents, documentary, foreign trade, business translation and so on after graduation. The specific requirements are: a more solid English language foundation, including five aspects of language skills in English listening, speaking, reading, writing and translation; good English communication ability refers to communicate fluently in English in daily life and business activities; to master a wide range of business and trade 
knowledge means to hold general theory of trade, legal knowledge and business operation, such as international trade and settlement, international finance, economic and trade contracts, international commercial law, import and export business and other aspects; using the modern office equipment skillfully means that you are familiar with office secretarial work and modern office equipment, such as fax machines, computers, office software and the Internet.

\section{The Problems Existing in Occupation Ability Cultivation of Business English Majors}

Too few specialized courses, and the curriculum construction lacks professional characteristics. Some colleges and universities did not deal with well on the relationship between language and professional direction. They overemphasis on systematicness and infotainment of English subject knowledge; their courses are excessively pursuit the perfection, which results that the content is simply to copy or compress undergraduate courses in English and can not see its own professional advantages and characteristics. The course has many repeat contents with fuzzy boundaries, and practice teaching is obviously insufficient.

Single classroom teaching methods with little creativity. Business English teaching mode should be conducive to the formation of students' individualized learning method and development of students' autonomous learning ability. Business English teaching mode should reflect the principles that integrate practicability, the culture and interest of the English teaching. Business English teaching mode should be able to fully mobilize the enthusiasm of students, activate classroom atmosphere and enhance students' understanding of teaching content. However, Business English teaching mode in some colleges and universities are still adopting the traditional teaching mode. The classroom teaching mode of "teachers talk, students note" leads to a serious gap between classroom teaching and practice.

Practice teaching is more in name than in reality. At present, many college and university teachers are accustomed to impart knowledge through classroom teaching. They do not have a clear understanding of how to carry out practical training in English majors, and are lack of systematic and operational implementation plan. They only arrange very short practical training for the teaching design of courses or only arrange ephemeral practice in the last semester. As a result, the total number of training hours accounted for the low proportion.

"Double qualified" teachers are not optimistic. The teachers engaging in Business English teaching with little business knowledge backgrounds and limited experience in applying foreign languages to jobs in social production practice teach directly after graduating from university, so that such occasion leads to repeat what the book says without any attractions. The main reason is that some colleges blindly emphasizes the introduction of highly educated graduates and high-grade teachers and ignores the cultivation of high-skilled teachers.

The assessment system is unreasonable. In addition to examination on the basic language knowledge, we should emphasize their language application abilities and focus on the ability to communicate in a practical language for the Business English majors. At present, most of the colleges and universities adopt the summative examination methods with little examinations and narrow knowledge on the test paper; in addition, such examination asks for more written than practical and more memory-based than understanding. This is not in line with the cultivating target of talents majoring in Business English.

\section{Occupation Ability Training Strategies for Business English Majors}

Optimize the curriculum system and integrate professional ability and the core competence of occupation. The cultivation of professional core competence is not simply a course of instruction, but a kind of behavior training with the purpose of training ability. We must infiltrate the training of these abilities into the curriculum based on project tasks. The professional competence of Business English majors refers to the ability to hear, read, write and interpret a foreign language, while the professional core competence is the ability described above. In the process of cultivating talents, we need to integrate these abilities organically. The relatively 
common construction way for the Business English is: general courses, vocational ability training course, occupation quality curriculum and occupation development course. The classification of the modules is more reasonable, which can reflect the characteristics of occupation education. The key question is what kind of curriculum to fill the content. The curriculum must first meet the market demand and regard it as the basic principles; based on extensive market research, we want to analyze graduate employment positions and find out the tasks from the field of action, and then select typical tasks from these tasks. Further, we want to find out the typical tasks of teaching value to develop curriculum, so that to form curriculum system. Secondly, we should embody the idea of combining professional ability with professional core competence. In the process of arranging our language courses and developing our professional skills, we should consider the courses that contribute to the development of professional core competencies. For example, communication and communication courses, training courses, debate courses and the cultural experience courses. Our ability to train Business English students should be systematical and comprehensive.

Scientifically design teaching methods, and classroom activities should focus on capacity-building. The student spend a lot of time on learning knowledge in the classroom at school, so the teaching contents and methods play a decisive role in cultivating the abilities of the students. With the initial success of the teaching reform, the integrated teaching model of teaching, learning and doing has been accepted by the school teachers. This teaching model is conducive to cultivate students' core ability of occupation. Business English majors attend about 30 courses at school. Although the teaching contents be quite different, the training methods are relatively uniform and not restricted by the professional and teaching content. General teaching design should increase the awareness of logical thinking training. General education courses are teaching through the mother tongue, so it is very helpful for students to improve thinking ability. In the classroom teaching, teachers should try to reduce the proportion of knowledge transfer, and some of the content of the textbooks can arrange for students to read after class. The classroom should focus on the design thinking, and create conditions for students to express opinions with phenomenon analysis and panel debates and other activities, so as to cultivate the thinking logic expression ability of mother language and communication ability for the students.

Reasonably arrange extracurricular activities to enhance the overall quality of students. Compared with other majors, the development of the thinking ability of language majors is an inevitable disadvantage. At least in the initial stage, both the learning content and learning methods are not enough to form the challenge for the level of students' thinking. However, the student has about forty percent of the extra spare time. Therefore, we should follow the principle of "extracurricular activity mends lacks in the class" and teachers should organize rich extracurricular activities for students, such as Chinese composition contest and debate contest and host competition. At the same time, we should arrange social practice or public welfare projects to go into the enterprise and exercise social activities, so that to improve the ability on dealing with the problem and lay good foundation for employment.

Reform the evaluation way to effectively evaluate students' ability. Influenced by the examination-oriented education for a long term, the Chinese students have certain anxiety and fear on test. Therefore, the evaluation mode must be changed, such as process assessment; the proportion of project achievements has risen and the percentage of the final written examination is down; the enterprise training evaluation methods can be more effective to assess the students' knowledge and ability level. When teachers evaluate students in a comprehensive way, they also need to consider factors such as students' professional accomplishment, tolerance, cultural ideas and so on.

Improve the awareness of teachers and strengthen the construction of teaching staff. The construction of teachers is the key to enhance the core competence of the students' occupation. Business English major teachers should not only have the systematic research on English language, but also cultivate students' core ability of occupation consciousness with effective combination of advanced teaching methods and language teaching methods at home and abroad. School teachers should be organized to make regular professional training, including vocational education teaching 
idea and professional core ability training method; moreover, the school should organize the teachers to practice and increase teachers' professional practice opportunities to make in-depth understanding of the connotation of the core ability of occupation and training mode, so that to actively explore in teaching. The school also can hire skilled craftsmen from company to design training programs for students. This calls combination of learning and training.

\section{Summary}

Cultivating professional core competence is a systematic project. We should set up the concept of sustainable development and adhere to the systematic principles. Based on the situation of professional education focusing on training students' employment ability and weak professional ability for the students majoring in language, schools and teachers should increase the degree of attention and consciously train the core ability of occupation, so that to further improve the Business English students' employment competitiveness.

\section{References}

[1] Qin Meng. Analysis of Post Skill Evaluation Standard for Business English Majors in Colleges and Universities[J]. Journal of Taiyuan City Vocational College, 2014, (06): 125-127.

[2] Cheng Lin. Research on Vocational Skills Cultivation of Business English Major in Higher Vocational Colleges[J]. Pioneering with Science and Technology, 2014, (06): 121-123.

[3] Wang Lili. Post Analysis of Business English Skills Evaluation Standard[J]. Knowledge Economy, 2014, (08): 165.

[4] Gao Feng. Analysis of Cultivation of Occupation Ability for Business English Majors in Higher Vocational Colleges[J]. Overseas English, 2011, (06): 19+36.

[5] Chen Pinrong. Research and Practice of Business English Major Based on the Cultivation of Students' Vocational Ability[J]. Journal of Huaihua College, 2010, (12): 133-135.

[6] Yang Xiaodong, Li Yingfen. Analysis of the Construction of Business English Major in Vocational Colleges under Vocational Competence[J]. Vocational Education Forum, 2010, (17): $47-48+51$. 